\title{
Progress and prospect for research on mountain glaciers in China
}

\author{
XIE ZICHU \\ Lanzhou Institute of Glaciology and Geocryology, Academia Sinica, Lanzhou 730000, China
}

\begin{abstract}
In the past decade the interest of many scientists worldwide has been attracted to the central Asian area of China. A number of gaps in scientific knowledge have been closed, and many significant discoveries have been made.

The most important achievement is the ice-core research by the Sino-American Joint Expedition to the Dunde Ice Cap, Qilian mountains, that established a record of ten thousand years of climatic and environmental change. In addition, in cooperation with scientists from Japan, Switzerland and the Soviet Union, studies have been carried out focusing on glacier mass balance, heat balance, the mechanism and formation of glacial runoff, and high mountain climates. This work has been done in the Tien Shan, west Kunlun, Tanggula, Nyaingentanglha and Gongga mountains.

In addition, through joint efforts of scientists from China, Nepal and Canada, important advances have also been made in studies of glacier lake outburst floods and debris flows in the Karakoram and the Himalayas, and in mountainous areas in southeastern Tibet.

The glaciers in central Asia will continue to be an important research area for glaciologists from all over the world in the coming decade.
\end{abstract}

\section{INTRODUCTION}

The mountainous region of Chinese central Asia is the largest glacierized area in the world outside the south and north polar regions. Owing to its high altitude, large area, middle-to-low latitude and intimate connection to human economic activities, this region occupies a special position in international scientific projects concerning both global change and the mitigation of natural calamities.

Systematic glaciological studies in this region were initiated in 1958 when a special institution, the present Lanzhou Institute of Glaciology and Geocryology of the Chinese Academy of Sciences, was established. Initially, the glaciers were taken as a water resource for arid regions. Therefore research was limited to mountain ranges adjacent to irrigated farmlands, such as the Qilian and Tien Shan mountains. Since the 1960s, expeditions have been extended to the Himalayas (Chinese Academy of Sciences, 1975). From these it was found that most of the glaciers in China possess features that distinguish them from glaciers in other mid-latitude regions, such as low accumulation rate, low ablation rate, low ice temperature, and low velocity. The prevalent concept of a temperate glacier did not fit these glaciers. Consequently, the concept of continental glaciers with special types of ice formation was proposed for glaciers in this region (Shi and Xie, 1964). In 1975, Chinese glaciologists carried out a large expedition to the Batura Glacier in the Karakoram in Pakistan. Additional glaciological expeditions were carried out on the southern Tibetan Plateau
(Li and others, 1986). Throughout the 1970s and during the 1980s, great progress was made in glaciological research in China, both in extent and intensity. The following is a brief review of these latter studies.

\section{PROGRESS IN GLACIOLOGICAL RESEARCH IN CHINA}

\section{Mass-balance studies}

Owing to the strong influence of the monsoon, the principal periods of accumulation and ablation overlap completely in most of this region. Thus the mass exchange processes of glaciers are different from those of glaciers nourished principally in the winter period (Fig. 1). Traditional research methods used in other parts of the world do not work well in this region. Thus, new concepts, new observational methods and new calculation procedures for such summer-nourished glaciers were suggested (Xie, 1980). Similar results were also obtained in studies on the south slope of the Himalayas by Ageta and Higuchi (1984) and a new concept of altitudinal structure of mass balance was proposed by Durgerov (1991).

\section{Physical characteristics of glaciers}

Boreholes to bedrock provide opportunities for study of ice temperature distribution in continental glaciers. 

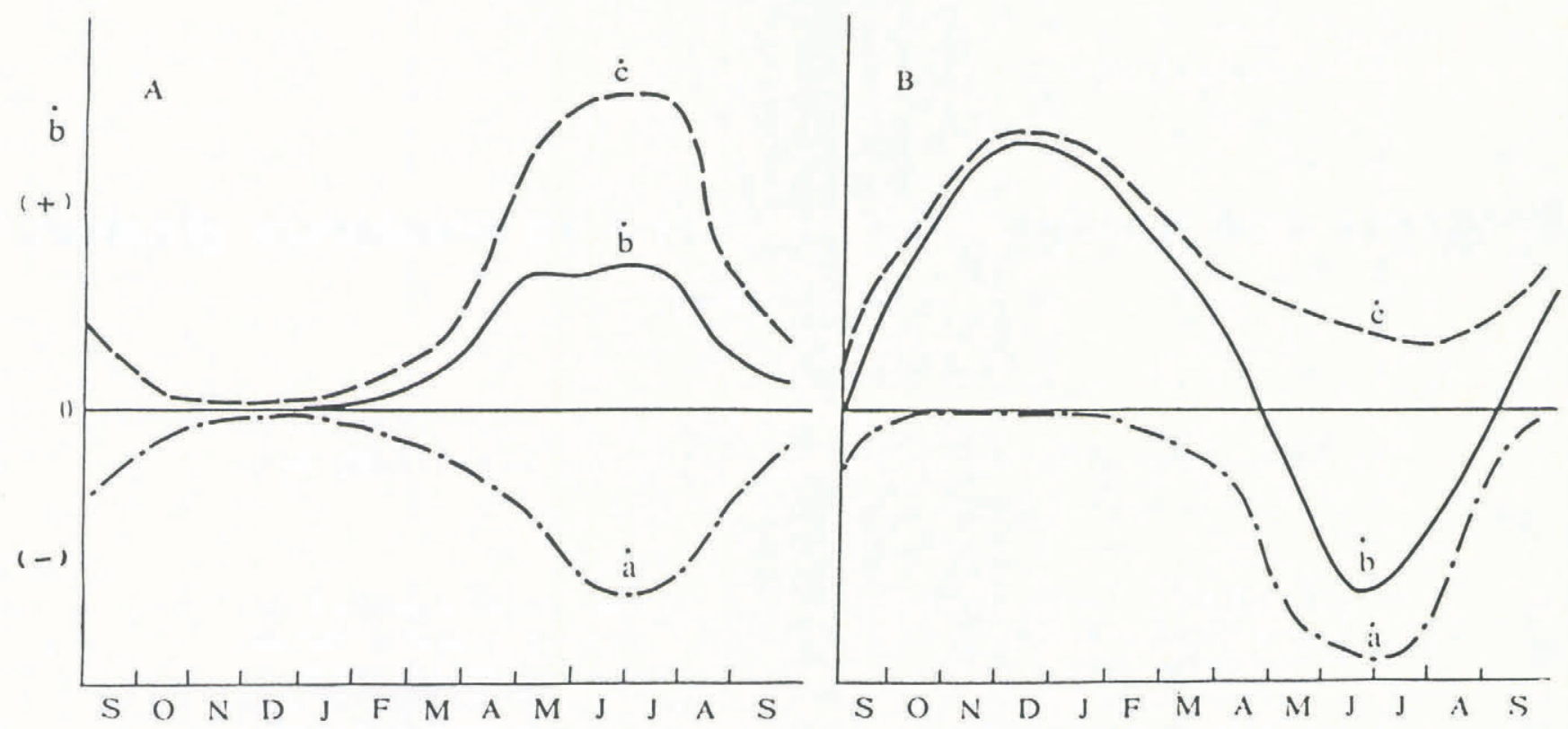

Fig. 1. Illustration of variation of accumulation (c), ablation (a) and net balance (b) for glaciers of the summeraccumulation type $(A)$ and the winter-accumulation type $(B)$ in the accumulation area.

Observations on Glacier No. 1 in the headwaters of the Ürümqi River, Tien Shan mountains, show that as a result of the influence of infiltration, the minimum ice temperature is not near the equilibrium line, but rather in the upper part of the ablation zone (Cai and others, 1988). At the bottom $(138 \mathrm{~m})$ of the Dunde Ice Cap in the Qilian mountains, the ice temperature is $-4.7^{\circ} \mathrm{C}$, which is lower than expected (Wang, 1990).

Observations in an artificial ice tunnel at the bottom of Glacier No. 1 show that a signficiant part of the glacier flow occurs through deformation in a debris-laden ice layer at the bottom. This may be the principal mode of movement of some cold glaciers (Echelmeyer and Wang, 1987). Further study shows that there are shear planes in this debris-laden ice layer.

\section{Ice cores}

Between 1984 and 1987, the Chinese-American expeditions to Dunde Ice Cap were carried out. Three boreholes were drilled to bedrock and nearly continuous core was obtained. The oldest ice dates back to the last glaciation. Microparticles are plentiful. $\delta^{18} \mathrm{O}$ ratios and concentrations of $\mathrm{NO}_{3}, \mathrm{SO}_{4}{ }^{2-}$ and $\mathrm{Cl}^{-}$are very low. The climatic optimum of the Holocene occurred before $6000-8000$ a $B P$. The past 60 years has been the warmest period in the Holocene (Thompson and others, 1989). The core also contains a detailed record of two warm periods and two cold periods during the Little Ice Age (Fig. 2) (Yao and others, 1991).

\section{Glacier lake outburst floods}

Between 1985 and 1987, glaciologists from Lanzhou Institute of Glaciology and Geocryology and hydrologists from Xingjiang Uygur Autonomous Region carried out a systematic investigation in the headwaters of the Yarkant River, aimed at obtaining a better under- standing of mechanisms of glacier lake outbursts and at predicting the occurrence of such floods. It was found that a lake there was formed by an advance of two $20 \mathrm{~km}$ long glaciers which dammed the valley. An outburst resulted from the rapid enlargement of subglacial channels when the lake level became sufficiently high. There was no

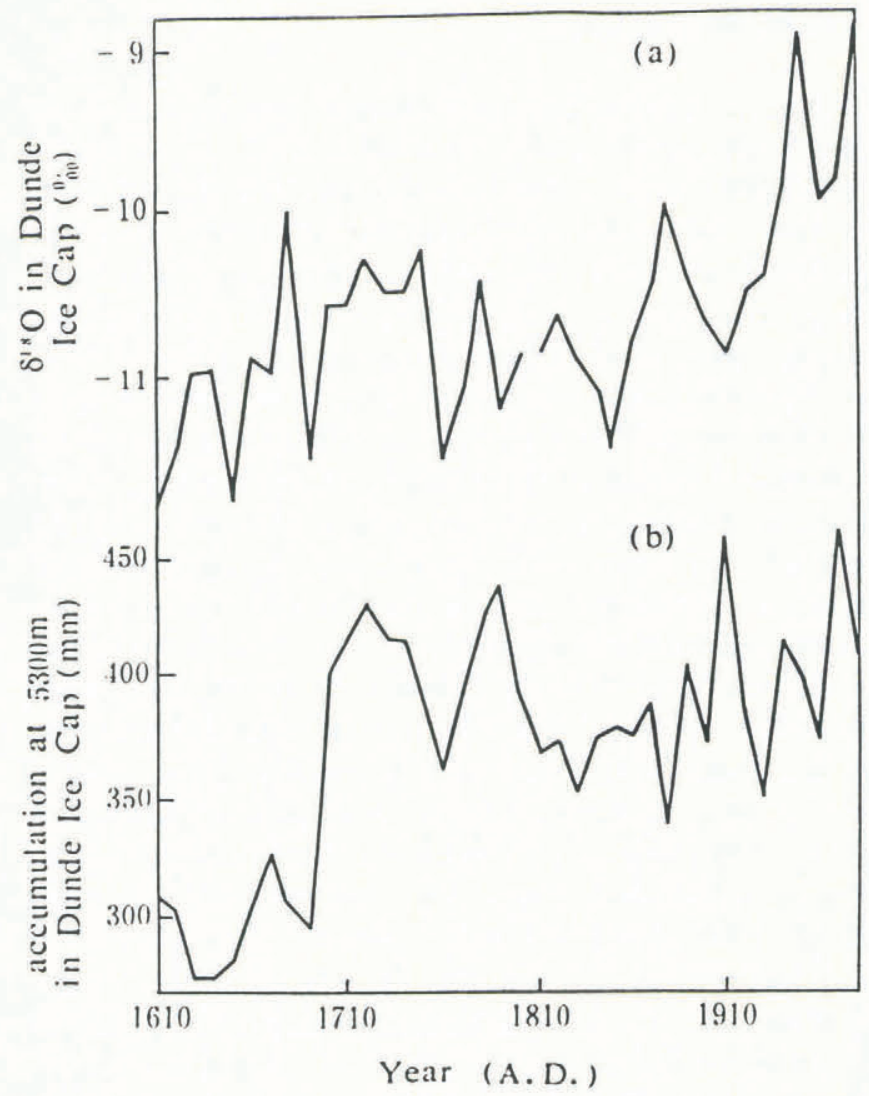

Fig. 2. Temperature $\left(\delta^{18} \mathrm{O}\right)$ and precipitation (glacial accumulation) fluctuations recorded in the Dunde ice core (reproduced from Yao and others, 1991). 


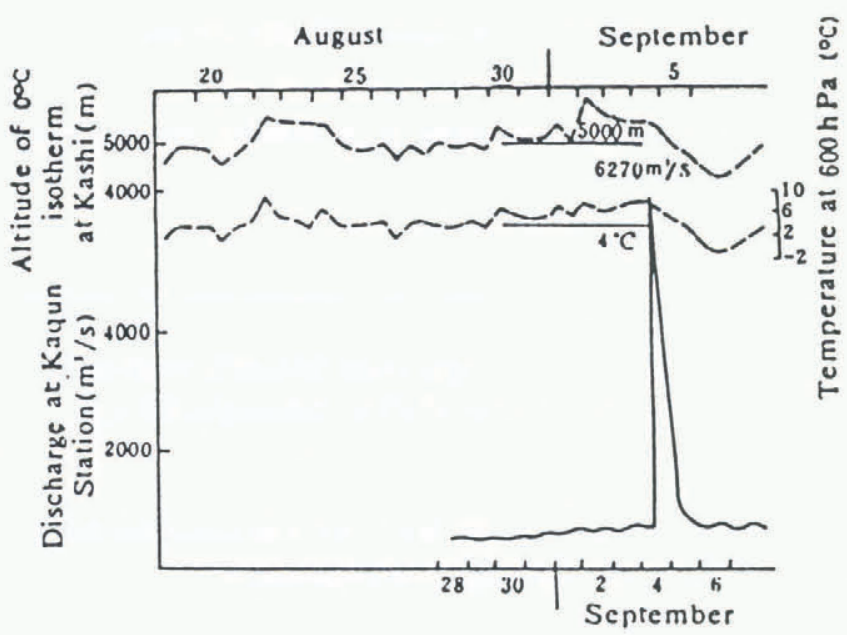

Fig. 3. Hydrograph of the 1961 glacial flood of the rarkant River (reproduced from Feng and Liu, 1990).

direct correlation with air temperature (Fig. 3) (Feng and Liu, 1990).

In 1987, scientists from China, Canada, and Nepal investigated dangerous moraine-dammed lakes on the north flank of the Himalayas. An inventory of glacier lakes was completed (Liu and Sharma, 1988).

In 1990, Chinese scientists made an expedition to southeastern Tibet and found that outburst floods there may be caused by surging of glaciers (personal communication from Zhang Wenjing).

\section{Glaciers as water resources}

During the past decade, the following developments in research on glaciers as water resources have occurred:

\section{a. Glacier inventory}

$80 \%$ of the glacier inventory in China has been finished. The inventory of glaciers in the Himalayas and southeastern Tibet is delayed due to the wide distribution and high altitude of glaciers there, and the consequent arduous field conditions and lack of aerial photographs. It is estimated that the total area of glaciers in China is about $58000 \mathrm{~km}^{2}$.

\section{b. Hydrometeorological studies}

Hydrometeorological studies have been carried out mainly in the Ürümqi River basin. One of the most prominent investigations involved cooperation between Chinese and Swiss scientists between 1985 and 1987. Heat balances on glaciers and precipitation in high mountainous areas were observed and analyzed. Additional results were obtained during a joint Chinese-Japanese expedition to the Kunlun mountains (Higuchi and Xie, 1989).

\section{c. Forecasting runoff from snow cover by remote sensing}

During the past several years, Lanzhou Institute of Glaciology and Geocryology had been endeavouring to monitor and forecast snowmelt runoff in the headwaters of the Yellow River, using NOAA images. Results of forecasts have been used to adjust reservoir capacity at large hydroelectric stations in the upper reaches of the Yellow River (Zeng, 1990; Feng and others, 1990).

\section{CHARACTERISTICS OF GLACIOLOGICAL RE- SEARCH IN CHINA}

The following three changes characterize the development of glaciological research in China during the past decade.

1. The research area has expanded rapidly to all parts of the region in a short time. In addition, the number of research topics has increased greatly and new research techniques have been applied.

2. Traditional research that viewed glaciers as a water resource gave way gradually to studies emphasizing variations of glaciers and their relationship to climatic and environmental change. In addition, measures for mitigation of snow-ice hazards were sought, and geographical studies on glacier surfaces were supplanted by glaciodynamical and other studies on the frontiers of science.

3. The most notable aspect of glaciological research in China is its internationalization. China's "open door" policy provided a chance for scientists abroad to share in studies of the largest glacier-permafrost zone in the middle and low latitudes. During the past ten years, extensive international scientific cooperation has developed among scientists from China, Japan, the USA, the

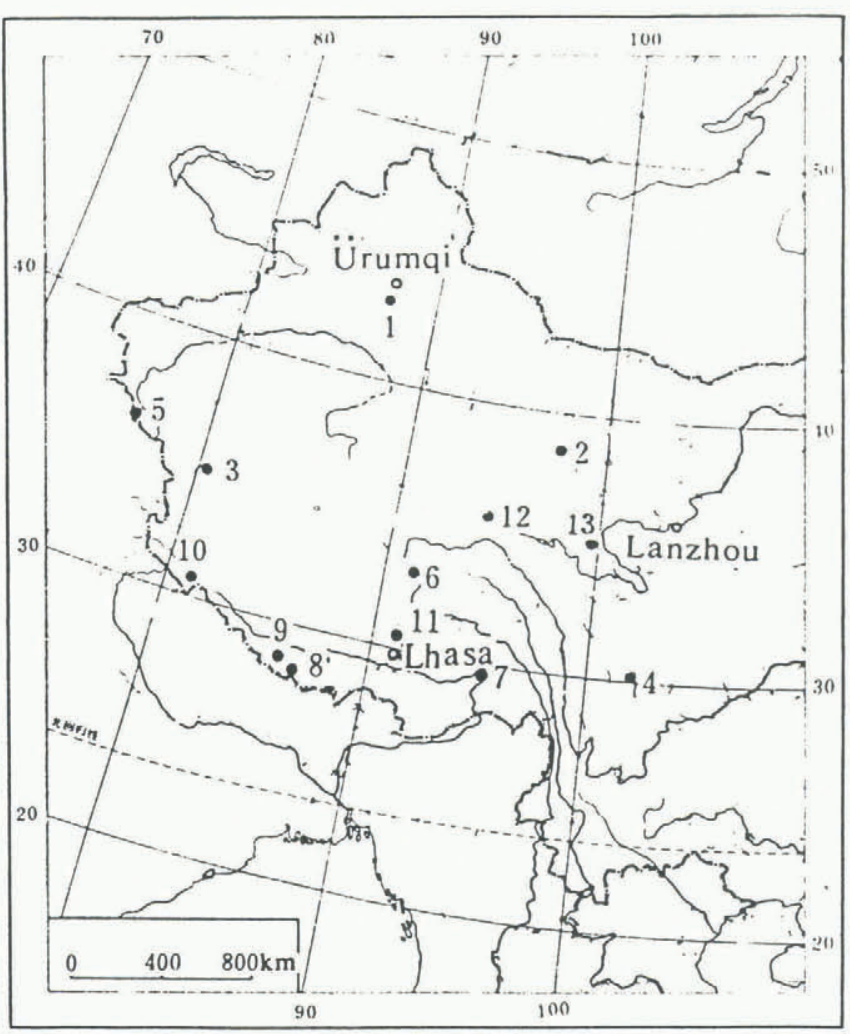

Fig. 4. Map of places where international glaciological studies have been carried out in China since 1981. Numbers refer to projects listed in Table 1. 


$\begin{array}{llll}\text { No. (see Region or } & \begin{array}{l}\text { Collaborating } \\ \text { countries }\end{array} & \text { Year } & \text { Subjects } \\ \text { Fig. } 4) \text { glacier } & & \end{array}$

\section{Glaciological \\ Station,}

Tien Shan

2

Dunde Ice Cap, Germany,
Qilian mountains

3 Chongce Ice Cap Japan

and Guliya Ice Cap, USA

west Kunlun

mountains

5

6

$$
\text { Tanggula }
$$

mountains

7

Nanjagbarwa,

Himalayas

8 Qomolangma,

Himalayas

9 Xixiabangma,

Himalayas

10 Namulaly,

Himalayas

1

Nyainqêntangla

Range

12

Eastern Kunlun Japan
mountains

13

Germany

Japan

Japan

Germany

A'nyêmaqên

Germany
Japan, USA,

Switzerland, USSR

Germany, Finland

Germany, $\quad 1981$

1984-87

1987, 1991

1990, 1991

1990

1986

1989-91

1989

1990

1989

1984

1987

USSR, USA

1984

1991

1985

1989

1989

mountains
Hydrometeorology, mass balance, physics of glaciers, ice-core studies, palaeoglaciology

Palaeoglaciology, ice cores, glaciometeorology, physics of glaciers, mass balance

Ice cores, hydrometeorology, hydrology, mass balance, palaeoglaciology, physics of glaciers

Mass balance, hydrometeorology, structure of glaciers, ice-core studies, palaeoglaciology

Palaeoglaciology, hydrometeorology, glaciology, glacier lake outburst floods

Mass balance, hydrometeorology, ice-core studies, palaeoglaciology

Palaeoglaciology, glacier lake outburst floods, meteorology

Palaeoglaciology, meteorology, glacier lake outburst floods

Palaeoglaciology, mass balance, meteorology, ice cores, physics of glaciers

Palaeoglaciology, meteorology

Hydrometeorology, mass balance, palaeoglaciology

Mass balance, meteorology, palaeoglaciology

Palaeoglaciology, glaciology
Soviet Union, Switzerland, Germany and so forth, and much progress has been made as a result. Table 1 lists collaborative research in China in the past decade, and Figure 4 shows the locations of these studies.

\section{FUTURE PROSPECTS}

The above studies will continue along the following lines.

1. Along with development of international projects on global change, ice-core research will intensify. Ice cores drilled from high plateaux of Asia will be of significant scientific value for their unique characteristics, which include low accumulation rate, low ice temperature and low strain rate.

2. With the commencement of the International Glacier Year in 1992, a number of synchronous monitoring projects will be carried out on glaciers in central Asia. Studies of glaciers as indicators of climate variation will become more significant. 
3. In conjunction with the commencement of the International Decade of Natural Disaster Reduction, local governments will focus more attention on forecasting and mitigating snow and ice disasters. This offers opportunities for intensive research on such disasters. The Himalayas and southeastern Tibet will become a focal point for such research.

4. As a result of the increase in atmopsheric $\mathrm{CO}_{2}$ and the consequent global warming, central Asia will become warmer and more arid (Shi and Ren, 1990). In this region, variations of glaciers, which serve as valuable water resources, will attract more attention. Therefore, forecasting glacier variations and modelling of climateglacier runoff will be further encouraged.

5. As a result of relaxation of international tensions, as well as the economical and political reforms appearing in many countries, glaciological research in central Asia will become more active and promising in the coming decade.

\section{REFERENCES}

Ageta, Y. and K. Higuchi. 1984. Estimation of mass balance components of a summer-accumulation type glacier in the Nepal Himalaya. Geogr. Ann., 66A(3), 249-255.

Cai Baolin, Huang Maohuan and Xie Zichu. 1988. A preliminary research on the temperature in deep boreholes of Glacier No. 1, Ürümqi River headwaters. Kexue Tongbao (Science Bulletin), 33(24), 2054 2056.

Chinese Academy of Sciences. 1975. Report of scientific expedition in the region of Qomolongma Peak (glaciology and geomorphology). Beijing, Science Press. [In Chinese.]

Durgerov, M. 1991. Cause and mechanism of fluctuation of alpine glaciers. 7. Glaciol. Geocryol., 13(2), 95-106. [In Chinese with English abstract.]

Echelmeyer, K. and Wang Zhongxiang. 1987. Direct observation of basal sliding and deformation of basal drift at sub-freezing temperatures. F. Glaciol., 33(113), 83-98.

Feng Qinghua and Liu Jingshi. 1990. The characteristics of the GLOF in the Yarkant River. In Zhang Xiangsong and Zhou Yuchao, eds. Studies of GLOF in the Yarkand River, Karakoram. Beijing, Science Press, 4859. [In Chinese with English abstract.]
Feng Xuezhi, Wang Jian and Zeng Qunzhu. 1990. Information system on ice, snow and water resources of Animaqing region for satellite snowcover monitoring. In Tian Guoliang, ed. Dynamic research by remote sensing on typical region in the Yellow River valley. Beijing, Science Press, 50-61. [In Chinese with English abstract.]

Higuchi, K. and Xie Zichu., eds. 1989. Glaciological studies in west Kunlun mountains, 1987. Bull. Glacier Res. 7.

Li Jijun and Zhen Binxing, eds. 1986. Glacier in Xizang. Beijing, Science Press. [In Chinese.]

Liu Chaohai and C. K. Sharma, eds. 1988. Report on first expedition to glaciers and glacier lakes in the Pumqu and Poiqu river basins, Xizang, China. Beijing, Science Press.

Shi Yafeng and Ren Jiawen. 1990. Glacier recession and lake shrinkage indicating a climatic warming and drying trend in central Asia. Ann. Glaciol., 14, 261-265.

Shi Yafeng and Xie Zichu. 1964. Basic characteristics of the existing glaciers in China. Acta Geographica Sinica, 30(3), 183-208. [In Chinese with Russian abstract.]

Thompson, L. G. and 9 others. 1989. Holocene-Late Pleistocene climatic ice core records from QinghaiTibetan Plateau. Science, 246(4929), 474477.

Wang Lilun. 1990. A study of temperature regime on the Dunde Ice Cap. In Proceedings of the Fourth National Conference on Glaciology and Geocryology (Glaciology). Beijing, Science Press, 41-48. [In Chinese with English abstract.]

Xie Zichu. 1980. Mass balance of glaciers and its relationship with characteristics of glaciers. 7. Glaciol. Cryopedol., 2(4), 1-10. [In Chinese with English abstract.]

Yao Tandong, Xie Zichu, Wu Xiaoling and L. G. Thompson. 1991. Climatic change since Little Ice Age recorded by Dunde Ice Cap. Science in China, Ser. $B, 36(6), 760-767$.

Zeng Qunzhu. 1990. Summary of satellite snow cover monitoring and study on snowmelt runoff forecasting in the upper reaches of the Yellow River. In Tian Gouliang, ed. Dynamic research by remote sensing on typical region in the Yellow River valley. Beijing, Science Press, 113. [In Chinese with English abstract.]

The accuracy of references in the text and in this list is the responsibility of the author, to whom queries should be addressed. 